\title{
A novel enzyme-linked immunosorbent assay for detection of Escherichia coli 0157:H7 using immunomagnetic and beacon gold nanoparticles
}

\author{
Zhiqiang Shen ${ }^{1}$, Nannan Hou', Min Jin' ${ }^{1}$ Zhigang Qiu', Jingfeng Wang ${ }^{1}$, Bin Zhang ${ }^{1}$, Xinwei Wang ${ }^{1}$, Jie Wang², \\ Dongsheng Zhour ${ }^{2^{*}}$ and Junwen $\mathrm{Li}^{1^{*}}$
}

\begin{abstract}
This paper presents a functional nanoparticle-enhanced enzyme-linked immunosorbent assay (FNP-ELISA) for detection of enterohemorrhagic Escherichia coli (EHEC) O157:H7. Immunomagnetic nanoparticles (IMMPs) conjugated with monoclonal anti-O157:H7 antibody were used to capture E. coli O157:H7. Beacon gold nanoparticles (B-GNPs) coated with polyclonal anti-O157:H7 and biotin single-stranded DNA (B-DNA) were then subjective to immunoreaction with E. coli O157:H7, which was followed by streptavidin-horseradish peroxidase (Strep-HRP) conjugated with B-GNPs based on a biotin-avidin system. The solutions containing E. coli O157:H7, IMMPs, B-GNPs, and Strep-HRP were collected for detecting color change. The signal was significantly amplified with detection limits of $68 \mathrm{CFU} \mathrm{\textrm {mL } ^ { - 1 }}$ in PBS and $6.8 \times 10^{2}$ to $6.8 \times 10^{3} \mathrm{CFU} \mathrm{mL} \mathrm{m}^{-1}$ in the food samples. The FNP-ELISA method developed in this study was two orders of magnitude more sensitive than immunomagnetic separation ELISA (IMS-ELISA) and four orders of magnitude more sensitive than C-ELISA. The entire detection process of E. coli O157:H7 lasted only $3 \mathrm{~h}$, and thus FNP-ELISA is considered as a time-saving method.
\end{abstract}

Keywords: Escherichia coli O157:H7, ELISA, Immunomagnetic nanoparticles, Beacon gold nanoparticles

\section{Introduction}

The World Health Organization estimated that about 1.8 million people worldwide die every year from diarrheal diseases, which are often caused by consuming microbiologically contaminated food or by drinking water [1]. Among the pathogens causing diarrheal diseases, enterohemorrhagic Escherichia coli (EHEC) strains are prominently responsible for serious foodborne outbreaks [2,3]. In particular, E. coli O157:H7, a predominant strain of EHEC that was first isolated and recognized as a new type of intestinal pathogenic bacterium in the United States in 1982 [4], has become a global public health problem. E. coli O157:H7 outbreaks have occurred in many developing and developed countries, causing huge health care costs and product recalls. The Center for

\footnotetext{
* Correspondence: dongshengzhou1977@gmail.com; junwen9999@hotmail.com ${ }^{2}$ State Key Laboratory of Pathogen and Biosecurity, Beijing Institute of Microbiology and Epidemiology, Beijing 100071, China

${ }^{1}$ Tianjin Institute of Health and Environmental Medicine, Key Laboratory of Risk Assessment and Control for Environment and Food Safety, Tianjin 300050, China
}

Disease Control and Prevention of the United States estimated that 73,000 cases of illness and 61 deaths per year in the United States are caused by E. coli O157:H7 [5].

The development of a rapid and reliable detection of E. coli $\mathrm{O} 157: \mathrm{H} 7$ has become highly important for food safety and public health [6]. However, traditional methods for the detection of $E$. coli O157:H7 encompassing enrichment, plating, culturing, enumeration, biochemical testing, and microscopic examination can take up to $60 \mathrm{~h}$, thereby being laborious and time-consuming [7]. Polymerase chain reactions (PCRs), including simple PCR [8], multiplex PCR $[9,10]$, and real-time PCR [11,12], are commonly used for rapid detection of E. coli $\mathrm{O} 157: \mathrm{H} 7$, but require complex set-ups and well-trained personnel. In addition, some very sensitive and selective but expensive, complicated, and time-consuming methods have been applied in the detection of E. coli O157:H7, especially including immunomagnetic separation (IMS) analysis [13], flow cytometry [14], fluorescence in situ hybridization [15], DNA microarrays [16], and several label-free methods (such as surface

\section{Biomed Central}

(c) 2014 Shen et al.; licensee BioMed Central Ltd. This is an Open Access article distributed under the terms of the Creative Commons Attribution License (http://creativecommons.org/licenses/by/4.0), which permits unrestricted use, distribution, and reproduction in any medium, provided the original work is properly credited. The Creative Commons Public Domain Dedication waiver (http://creativecommons.org/publicdomain/zero/1.0/) applies to the data made available in this article, unless otherwise stated. 
plasmon resonance [17] and use of electrochemical impedance immunosensors $[18,19])$.

Enzyme-linked immunosorbent assay (ELISA) was reported to quantitatively detect immunoglobulin G in 1971 [20]. Conventional ELISA (C-ELISA) has high reproducibility and possibility for the simultaneous quantification of a great number of assays, and is widely used to detect the presence of substances, including bacteria [21], viruses [22], proteins [23], and pesticides [24]. However, the detection limit of C-ELISA to E. coli $\mathrm{O} 157: \mathrm{H} 7$ is only $10^{5}$ to $10^{7} \mathrm{CFU} \mathrm{mL} \mathrm{m}^{-1}$ [25], which is inadequate when the infectious dose is lower than 100 cells [26].

In recent years, the emergence of nanotechnology is opening new horizons for high detection limits in biological fields [27-30]. Nanoparticles of various shapes, sizes, and compositions have broad applications in microorganism detection [31,32]. Much attention has been focused on amplifying the detection signal using nanoparticles [33,34], which can enhance enzyme activity [35,36]. Magnetic and gold particles have been used to improve the detection limit of ELISA [30,37].

In this study, we developed a functional nanoparticleenhanced ELISA (FNP-ELISA) using immunomagnetic nanoparticles (IMMPs) and beacon gold nanoparticles (B-GNPs) for detecting E. coli O157:H7. The detection limit of E. coli $\mathrm{O} 157: \mathrm{H} 7$ by the developed FNP-ELISA is much higher than that of C-ELISA or immunomagnetic separation ELISA (IMS-ELISA), and thus FNP-ELISA had the highest sensitivity compared to the other ELISA methods.

\section{Materials and methods Reagents and materials}

Rabbit polyclonal anti-E. coli $\mathrm{O} 157: \mathrm{H} 7$ antibody and mouse monoclonal anti-O157:H7 antibody were prepared and purified in our laboratory. Single-stranded DNA 5'(biotin)-GCTAGTGAACACAGTT-GTGTAAAAAAAAAA (SH)-3' was synthesized by Sangon Biotech Co., Ltd. (China). Streptavidin-horseradish peroxidase (Strep-HRP) and peroxidase-conjugated affinipure goat anti-rabbit IgG (IgG-HRP) were purchased from Beijing Biosynthesis Biological Technology Co., Ltd. (China). Bovine serum albumin (BSA), 3,3',5,5' - tetramethylbenzidine (TMB$\mathrm{H}_{2} \mathrm{O}_{2}$ ), and hydrogen tetrachloroaurate (III) trihydrate $\left(\mathrm{HAuCl}_{4} \cdot 3 \mathrm{H}_{2} \mathrm{O}, 99.9 \%\right)$ were purchased from SigmaAldrich (USA). Dextran with a molecular weight of 40,000 (T-40) was obtained from Pharmacia (GE Healthcare, USA). Sorbitol-MacConkey agar (SMAC) and xyloselysine-tergitol 4 (XLT4) agar were purchased from Difco (Becton Dickinson, USA). Ferric chloride hexahydrate $\left(\mathrm{FeCl}_{3} \cdot 6 \mathrm{H}_{2} \mathrm{O}\right)$, ferrous chloride tetrahydrate $\left(\mathrm{FeCl}_{2}\right.$. $4 \mathrm{H}_{2} \mathrm{O}$ ), and other chemicals were of analytically pure grade or better quality. The buffer solutions were prepared in our laboratory. All aqueous solutions were prepared using ultrapure water $(18.0 \mathrm{M} \Omega / \mathrm{cm})$ as required.

\section{Preparation of microbial samples}

E. coli $\mathrm{O} 157: \mathrm{H} 7$ strain 35150 and E. coli $\mathrm{K} 12$ were obtained from the American Type Culture Collection (ATCC, USA). Salmonella senftenberg 50315, Shigella sonnei 51081, and E. coli O157:Hund strain 21531 (Hund indicated that $\mathrm{H}$ antigen was not determined) [38] were obtained from the Institute of Epidemiology and Microbiology, Academy of Preventive Medical Sciences of China. Pure cultures of bacteria were grown in nutrient broth at $37^{\circ} \mathrm{C}$ for $24 \mathrm{~h}$ before use. The concentrations of $E$. coli O157:H7, O157: Hund, and K12 were determined by the conventional surface plate count method using SMAC. S. senftenberg and $S$. sonnei were enumerated using XLT4 agar. The cultured bacteria were divided into two portions. The first portion was placed in a boiling water bath for 20 min to kill the bacterial cells, and diluted to the desired concentration with PBS (0.01 M, pH 7.4) for ELISA detection. The second portion was not heated because the number of living cells was counted.

Milk, vegetable, and ground beef were purchased from a local market in Tianjin (China), and each weighed $25 \mathrm{~g}(\mathrm{~mL})$ for detection. The killed E. coli O157:H7 solution was transferred into a small vial equipped with an atomizer. The mists of E. coli O157:H7 inoculums were sprayed onto the three samples, and the samples were then stored at $4 \pm 1^{\circ} \mathrm{C}$ for $1 \mathrm{~h}$. Each sample was added to $0.25 \mathrm{~mL}$ of $E$. coli $\mathrm{O} 157: \mathrm{H} 7$ solution. The samples were placed into sterile filter stomacher bags, and macerated in $225 \mathrm{~mL}$ of PBS with a stomacher blender (Bilon-8 Bilang Co. Ltd., Beijing, China) at $200 \mathrm{rpm}$ for $2 \mathrm{~min}$. The homogenate was serially diluted in PBS for ELISA detection. The negative samples that were not added to $E$. coli O157: $\mathrm{H} 7$ solution were analyzed according to the Chinese National Standard Method GB/T 4789.36-2008 [39].

\section{Preparation of IMMPs}

Magnetic nanoparticles (MPs) were prepared from $\mathrm{FeCl}_{3}$, $\mathrm{FeCl}_{2}$, ammonia solution, and dextran (T-40), and oxidized with $\mathrm{NaIO}_{4}$ as described previously [40]. Mouse monoclonal anti-E. coli $\mathrm{O} 157: \mathrm{H} 7$ antibody $(0.5 \mathrm{mg} / \mathrm{mL})$ was added to the oxidized MP suspension at a ratio of 0.3:1, mixed thoroughly, and incubated in the dark at $4^{\circ} \mathrm{C}$ for approximately $24 \mathrm{~h}$. IMMPs were washed three times with PBS by placing a magnetic plate against the side wall of the tubes for $5 \mathrm{~min}$ to concentrate the particles into the pellets on the side walls. The supernatant was discarded using a transferpettor. The pellets were resuspended in $1 \mathrm{~mL}$ of PBST $(0.05 \%$ Tween-20 in $0.01 \mathrm{M} \mathrm{PBS}, \mathrm{pH}$ 7.4). BSA was then added to a final concentration of $1 \%$ to block any unreacted or nonspecific site. The amount of IMMPs, incubation time, and separation time varied 
to determine their effects on the recovery of O157:H7 (details in Supplementary Materials).

\section{Preparation of GNPs}

GNPs were prepared according to the literature with slight modifications [41]. In brief, $2 \mathrm{~mL}$ of $1 \% \mathrm{HAuCl}_{4}$ was mixed with $198 \mathrm{~mL}$ of fresh ultrapure water. The mixture was stirred vigorously with a magnetic agitator while being heated in a boiling water bath for $20 \mathrm{~min}$, followed by the rapid addition of $5 \mathrm{~mL}$ of $1 \%$ sodium citrate solution. After the color finally turned to full red, the mixture was stirred again for 10 min before cooling to room temperature. The GNP solution was filtered through a $0.22 \mu \mathrm{m}$ cellulose nitrate filter to remove any floating aggregates. The prepared GNPs were characterized using a transmission electron microscope (TEM; Tecnai G2 F20, FEI, Netherlands) and ultraviolet spectrophotometer (UV 2500, Shimadzu, Japan).

\section{Preparation of various B-GNPs}

B-GNPs were prepared following a previously reported procedure $[42,43]$ with slight modifications. Rabbit polyclonal anti-E. coli O157:H7 antibody $(7 \mu \mathrm{g})$ was added to $1 \mathrm{~mL}$ of $\mathrm{pH}$-adjusted GNP solution ( $\mathrm{pH}$ 8.2) and incubated at room temperature for $30 \mathrm{~min}$. The mixture was added with $30 \mu \mathrm{L}$ of different concentrations of B-DNA, and incubated in the dark at $4^{\circ} \mathrm{C}$ for more than $16 \mathrm{~h}$. Approximately $100 \mu \mathrm{L}$ of $1 \%$ sodium chloride solution was then added to the mixture, and incubated at $4{ }^{\circ} \mathrm{C}$ for $3 \mathrm{~h}$. BSA was added to a final concentration of $1 \%$ to block any unreacted or nonspecific site. The prepared B-GNP solution was centrifuged at 20,000 $\mathrm{g}$ for $1 \mathrm{~h}$ at $4^{\circ} \mathrm{C}$. The final deposition was suspended in $0.5 \mathrm{~mL}$ of storage buffer (PBS, $0.01 \mathrm{M}, \mathrm{pH} 7.4,1 \% \mathrm{BSA}, 0.02 \% \mathrm{NaN}_{3}$ ) and stored at $4^{\circ} \mathrm{C}$.

\section{C-ELISA}

Mouse monoclonal anti-E. coli O157:H7 antibody $(100 \mu \mathrm{L}$ of $5 \mathrm{mg} \mathrm{L}^{-1}$ ) was added to a 96-well plate and incubated at $37^{\circ} \mathrm{C}$ for $2 \mathrm{~h}$. The plate was rinsed with PBST $(0.05 \%$ Tween-20 in 0.01 M PBS, pH 7.4) three times to remove unbound antibodies, followed by the addition of $100 \mu \mathrm{L}$ of PBS-BSA (1\% BSA in 0.01 M PBS, pH 7.4) and incubation at $4^{\circ} \mathrm{C}$ for $12 \mathrm{~h}$. Different concentrations of $E$. coli O157: $\mathrm{H} 7(100 \mu \mathrm{L})$ were added to each well and reacted at $37^{\circ} \mathrm{C}$ for $1 \mathrm{~h}$. After rinsing three times, $100 \mu \mathrm{L}$ of $5 \mathrm{mg} \mathrm{L}^{-1}$ rabbit polyclonal anti-E. coli $\mathrm{O} 157: \mathrm{H} 7$ antibody was added to the plate incubated at $37^{\circ} \mathrm{C}$ for $1 \mathrm{~h}$. Subsequently, 100 $\mu \mathrm{L}$ of $0.02 \mathrm{mg} \mathrm{L}^{-1}$ IgG-HRP was added to the plate and incubated for $1 \mathrm{~h}$ at $37^{\circ} \mathrm{C}$. The plate was rinsed three times to remove unbound IgG-HRP. Finally, $100 \mu \mathrm{L}$ of TMB$\mathrm{H}_{2} \mathrm{O}_{2}$ solution was added to each well and incubated at $37^{\circ} \mathrm{C}$ for $15 \mathrm{~min}$. The reaction was terminated using 100 $\mu \mathrm{L}$ of $0.5 \mathrm{M}$ sulfuric acid, and the absorbance at $450 \mathrm{~nm}$ was measured using a microplate reader.

\section{IMS-ELISA}

E. coli O157:H7 was separated using IMMPs according to the previous procedure in Supplementary Materials, and the particle-bacteria complex $(100 \mu \mathrm{L})$ was finally resuspended. Rabbit polyclonal anti-O157:H7 antibody (100 $\mu \mathrm{L}$ of $5 \mathrm{mg} \mathrm{L}^{-1}$ ) was added to the complex, and incubated at room temperature for $30 \mathrm{~min}$. The unbound antibody was removed by the magnetic plate method. The particle-bacteria-antibody complex was resuspended using $100 \mu \mathrm{L}$ of $0.02 \mathrm{mg} \mathrm{L}^{-1}$ IgG-HRP, and incubated for $1 \mathrm{~h}$ at $37^{\circ} \mathrm{C}$. The complex was resuspended and transferred to a 96-well plate after excess IgG-HRP was removed by the magnetic plate method. Finally, TMB- $\mathrm{H}_{2} \mathrm{O}_{2}$ and sulfuric acid were subsequently added, and the plate was read at $450 \mathrm{~nm}$ using a microplate reader.

\section{FNP-ELISA}

IMMPs $(10 \mu \mathrm{L})$ were added to $1 \mathrm{~mL}$ of $E$. coli $\mathrm{O} 157: \mathrm{H} 7$

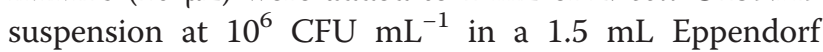
tube. The tube was carefully inverted several times and incubated at room temperature for $10 \mathrm{~min}$. Approximately $100 \mu \mathrm{L}$ of the complex of E. coli O157:H7 and IMMPs was obtained by the magnetic plate method. Various BGNPs $(100 \mu \mathrm{L})$ were added to $100 \mu \mathrm{L}$ of the complex, and incubated at room temperature for $30 \mathrm{~min}$. The unbound B-GNPs were removed by the magnetic plate method, and the complex was rinsed three times with PBST. Subsequently, $100 \mu \mathrm{L}$ of Strep-HRP $\left(0.01 \mathrm{mg} \mathrm{L}^{-1}\right)$ solution was added to the Eppendorf tube and incubated at $37^{\circ} \mathrm{C}$ for 1 h. The unbound Strep-HRP was removed by the magnetic plate method. The final complex was washed three times with PBST by the magnetic plate method, and resuspended in $100 \mu \mathrm{L}$ of PBS. The suspension was then transferred to a 96-well plate. Finally, TMB- $\mathrm{H}_{2} \mathrm{O}_{2}$ and sulfuric acid were subsequently added, and the plate was read at $450 \mathrm{~nm}$ using a microplate reader.

\section{Experimental replicates and statistical methods}

All the experiments were done with at least biological replicates, and the values were expressed as mean \pm standard deviation. A conventionally used positive control to negative control $(\mathrm{P} / \mathrm{N})$ value $\geq 2.1$ was considered positive in the three ELISA methods [44]. When needed, paired Student's $t$-test was performed to determine statistically significant differences; $P<0.01$ was considered to indicate statistical significance.

\section{Results and discussion Properties of IMMS}

We prepared MPs that were roughly spherical in shape with diameters ranging from 40-60 nm, and contained an 


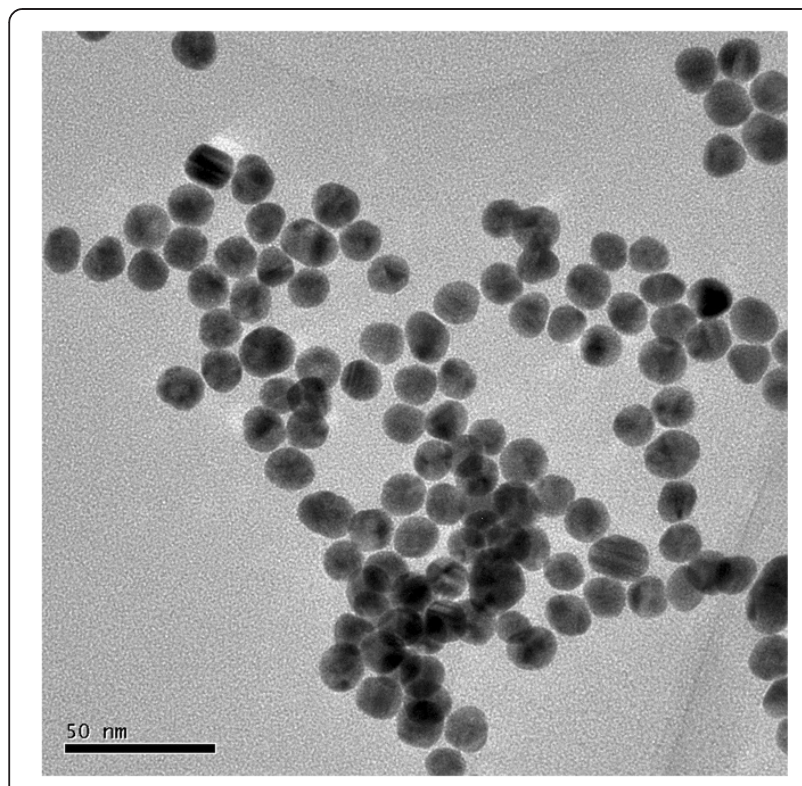

Figure 1 Typical TEM images of GNPs.

electron-dense core of $5 \mathrm{~nm}$ (Additional file 1: Figure S1). We also prepared IMMPs, and the recovery of IMMPs increased with increasing amount of IMMPs and incubation time. Relatively high recovery was obtained with $10 \mu \mathrm{L}$ of IMMPS (Additional file 1: Table S1) and $10 \mathrm{~min}$ of incubation (Additional file 1: Table S2). The optimal time for separation was 2 min (Additional file 1: Table S3). This finding was supported by a previous study, which showed that target cells can be separated from samples using MPs coupled with aptamer/nucleic acid/antibody $[45,46]$.

\section{Properties of B-GNPs}

We successfully prepared GNPs with an average diameter of approximately $18 \mathrm{~nm}$ as measured by TEM (Figure 1). The maximum peak of GNP solution was $518 \mathrm{~nm}$ as determined by UV scanning. We prepared a new type of GNP, namely, B-GNPs, which could target E. coli O157: H7 through the polyclonal antibody and amplify signals through the biotin-avidin Strep-HRP system.

\section{Experimental design for FNP-ELISA}

In this study, a novel ELISA method namely FNP-ELISA was established to detect $E$. coli $\mathrm{O} 157: \mathrm{H} 7$, in comparison with C-ELISA, and IMS-ELISA. A schematic diagram illustrating the detection of E. coli $\mathrm{O} 157: \mathrm{H7}$ by FNPELISA is presented in Figure 2.

First, functional monoclonal anti-E. coli $\mathrm{O} 157: \mathrm{H} 7-$ conjugated IMMPs and polyclonal anti-E. coli O157:H7 antibody and B-GNPs are prepared (A). Second, IMMPs are mixed with a sample to target E. coli $\mathrm{O} 157: \mathrm{H} 7$, and the O157:H7-IMMP complex is separated using the magnetic plate method (step 1, B). Third, B-GNPs are added to target $E$. coli $\mathrm{O} 157: \mathrm{H} 7$ in the E. coli $\mathrm{O} 157: \mathrm{H} 7-$ IMMP complex (step 2, B), and the unbound B-GNPs are removed by the magnetic plate method (step 3, B).

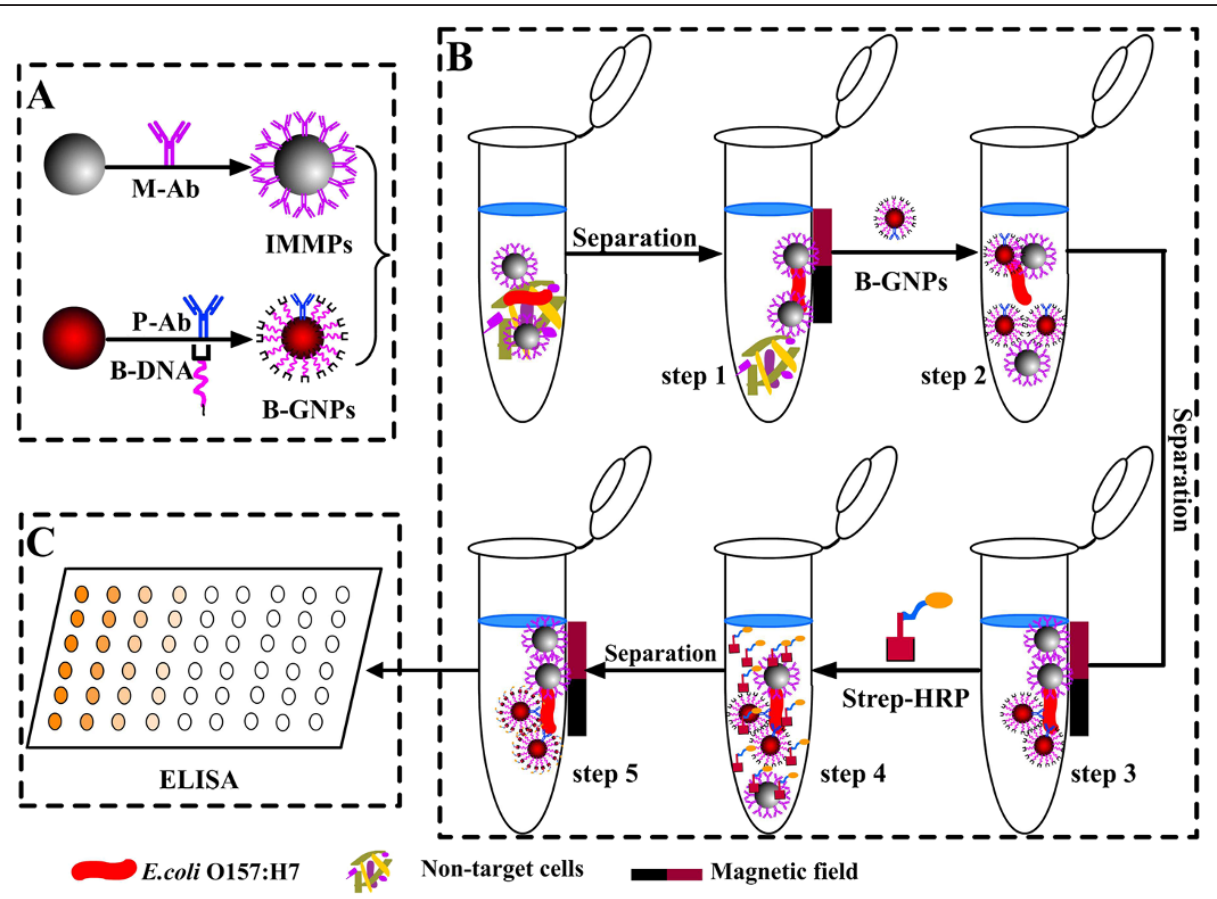

Figure 2 Flow chart of FNP-ELISA. Preparation of IMMPs and B-GNPS (part A); (part B) comprises five steps, namely, magnetic separation of target cells (step 1), conjugation of B-GNPs (step 2), removal of free B-GNPs (step 3), conjugation of Strep-HRP (step 4), and removal of free Strep-HRP (step 5); and FNP-ELISA detection (part C). 
Fourth, Strep-HRP is added to react with polyclonal anti-E. coli O157:H7 (step 4, B), and unbound Strep-HRP is removed by the magnetic plate method. Finally, the remaining routine ELISA steps are completed $(C)$.

\section{Optimized amounts of B-DNA, Strep-HRP and B-GNPs for FNP-ELISA}

The optimal amounts of B-DNA, Strep-HRP, and B-GNPs for FNP-ELISA were investigated (Figure 3). To obtain an optimized concentration of B-DNA, we added $100 \mu \mathrm{L}$ of different B-GNPs conjugated with different concentrations of B-DNA to the complex of E. coli O157:H7 and IMMPs after separating E. coli O157:H7. The aforementioned procedure was then repeated.

The optimal volume of B-GNPs was determined by adding different volumes of the optimized B-GNPs to the complex of E. coli O157:H7 and IMMPs after separating E. coli $\mathrm{O} 157: \mathrm{H} 7$. The detection procedure was then operated as above.
The optimized volume of Strep-HRP was determined when the optimized volume of B-GNPs was applied in the procedure. After optimizing the parameters, various concentrations of E. coli O157:H7 were detected in PBS using FNP-ELISA. The negative samples included K12, $S$. senftenberg, and S. sonnei in FNP-ELISA. This method was then used to determine the concentration of $E$. coli O157:H7 in the milk, vegetable, and ground beef samples.

We found that the FNP-ELISA signal increased with increasing B-DNA concentration (Figure 3a), and the optimal concentration of B-DNA was $40 \mu \mathrm{mol} \mathrm{L}^{-1}$. This finding was also observed in a previous study, which reported that excess B-DNA molecules cause excessive HRP molecules to bind with GNPs, posing steric hindrance to hamper antigens from access to antibodies on GNPs [47].

The signal of FNP-ELISA was strongly dependent on the amount of B-GNPs. The ELISA signal increased as the amount of B-GNPs increased, and reached a plateau at $100 \mu \mathrm{L}$ (Figure 3b). Thus, we used $100 \mu \mathrm{L}$ of B-GNPs
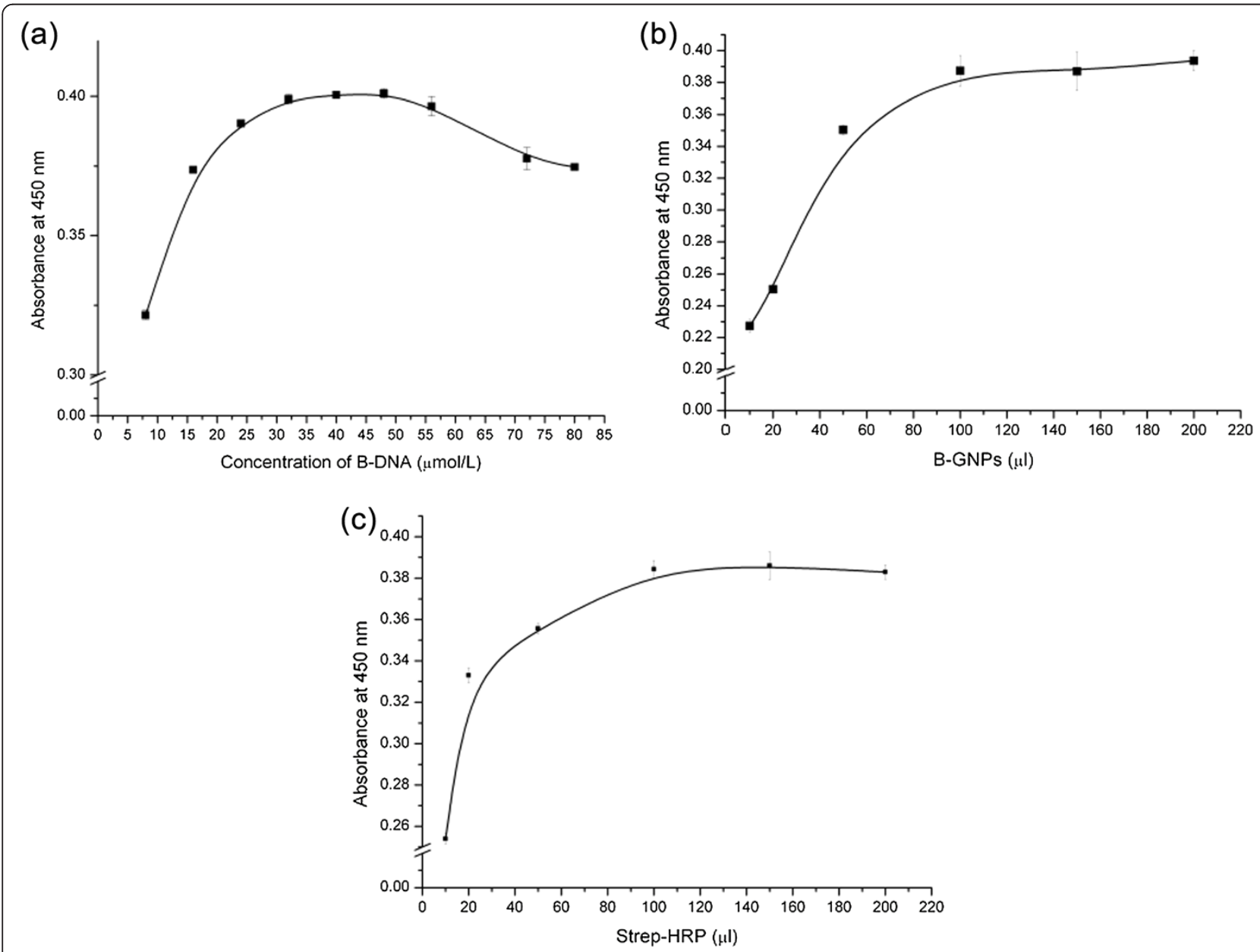

Figure 3 Optimal amounts of B-DNA, Strep-HRP, and B-GNPs. (a) Optimization graph of the B-DNA concentration in the preparation of B-GNPs. (b) Optimization of the B-GNP volume. (c) Strep-HRP volume optimization graph. 
in subsequent experiments. The optimal amount of Strep-HRP was also obtained at $100 \mu \mathrm{L}$ (Figure 3c).

\section{Comparison of FNP-ELISA to C-ELISA and IMS-ELISA}

Functional nanoparticles were used to improve the sensitivity of ELISA, and the results were compared simultaneously. The blank, positive, and negative controls were PBS, E. coli $\mathrm{O} 157: \mathrm{H} 7\left(10^{6} \mathrm{CFU} \mathrm{mL}{ }^{-1}\right)$, and E. coli $\mathrm{O} 157$ :Hund $\left(10^{6} \mathrm{CFU} \mathrm{mL} \mathrm{m}^{-1}\right)$, respectively. These controls were included on each plate in the experiments.

The surface plate counts showed that the concentrations of the test solutions of E. coli O157:H7, E. coli O157: Hund, K12, S. senftenberg, and S. sonnei were

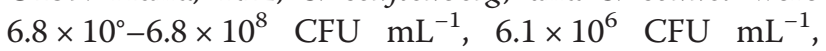
$7.1 \times 10^{\circ}-7.1 \times 10^{8} \mathrm{CFU} \mathrm{mL}{ }^{-1}, 8.1 \times 10^{\circ}-8.1 \times 10^{8} \mathrm{CFU}$

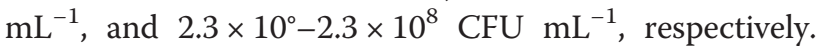
The detection limits of C-ELISA, IMS-ELISA, and FNPELISA were $6.8 \times 10^{5}(n=3,1.8 \leq \mathrm{RSD} \leq 4.7), 6.8 \times 10^{3}$ $(n=3,0.6 \leq \mathrm{RSD} \leq 5.2)$, and $68 \mathrm{CFU} \mathrm{mL} \mathrm{mL}^{-1}(n=3,0.3 \leq$ RSD $\leq 4.7$ ) in PBS, respectively (Figure 4). The three ELISA methods had high reproducibility, and all RSD values were lower than 10 .

The specificity of the three ELISA methods was dependent on the quality of the antibody. The specificity of the rabbit polyclonal anti-E. coli $\mathrm{O} 157: \mathrm{H} 7$ antibody and mouse monoclonal anti-E. coli O157:H7 antibody was tested using 61 bacteria, and false negative and false positive results were not observed (data not shown). E. coli $\mathrm{O} 157: \mathrm{H} 7$ is a common intestinal pathogen, so $S$. senftenberg and $S$. sonnei, which are also common intestinal pathogens, were selected as negative samples. E. coli $\mathrm{K} 12$, which represented $E$. coli, was another negative sample. The $\mathrm{P} / \mathrm{N}$ values of the negative signals were all significantly lower than 2.1 (Figure 4), which shows that FNP-ELISA had high specificity.

E. coli $\mathrm{O} 157: \mathrm{H} 7$ was not detected in the raw vegetable, milk, and ground beef samples using GB/T method 4789.36-2008. The detection limits of FNP-ELISA were $6.8 \times 10^{2} \mathrm{CFU} \mathrm{\textrm {mL } ^ { - 1 }}$ in vegetable and milk, and $6.8 \times 10^{3}$ CFU mL $\mathrm{mL}^{-1}$ in ground beef. The reduction in sensitivities may be attributed to the loss of some functional nanoparticles and targeting bacteria in the food residues, particularly grease foods.

\section{Concluding remarks}

Multiple ultrasensitive methods for detecting E. coli O157:H7 have been reported $[48,49]$, but they usually require expensive equipment or skilled personnel and thus have difficulty in wide use. C-ELISA has been widely established to detect microorganisms, proteins, pesticides, and heavy metals because of its simplicity and low cost, but its application is limited because of its low detection limit. Data presented here indicated that FNPELISA had a high sensitivity in detecting E. coli O157: $\mathrm{H} 7$, with a detection limit of $68 \mathrm{CFU} \mathrm{mL} \mathrm{mL}^{-1}$ in PBS and $6.8 \times 10^{2}$ to $10^{3} \mathrm{CFU} \mathrm{mL} \mathrm{m}^{-1}$ in foods. The detection limit of FNP-ELISA was about two or four orders of magnitude lower than that of IMS-ELISA or C-ELISA, respectively. Moreover, the total analysis time of FNP-ELISA was only approximately $3 \mathrm{~h}$. Therefore, FNP-ELISA may be used for detection of $E$. coli $\mathrm{O} 157: \mathrm{H} 7$ in foods, and also for other microorganisms if appropriate antibodies are available.

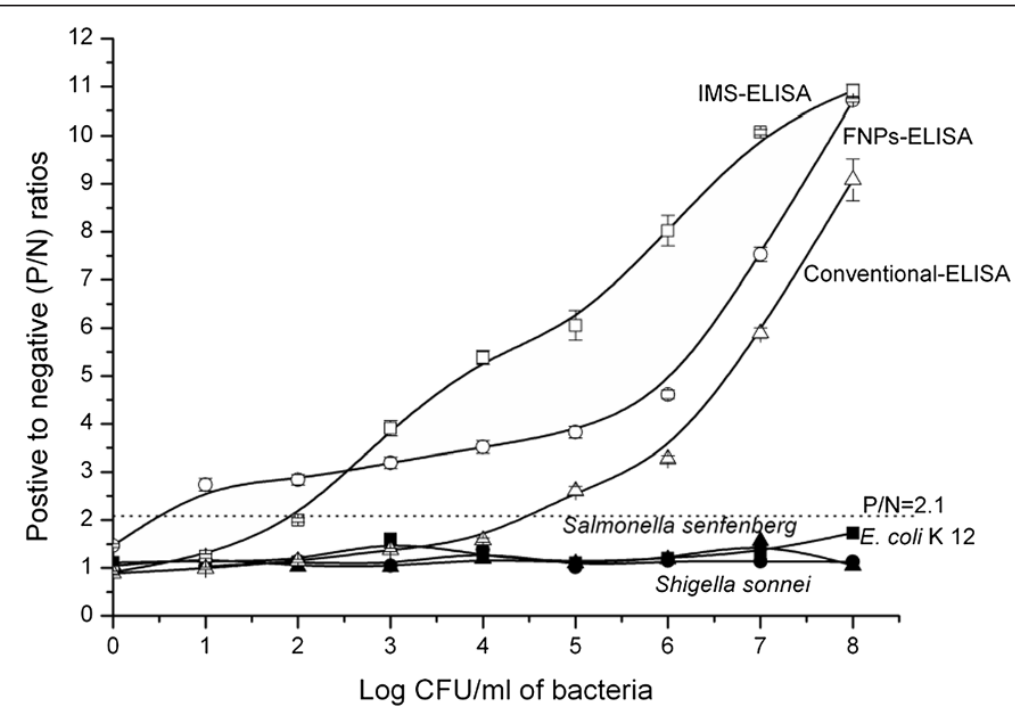

Figure 4 ELISA Detection sensitivity. The detection limits of C-ELISA, IMS-ELISA, and FNP-ELISA were $6.8 \times 10^{5}(1.8 \leq \mathrm{RSD} \leq 4.7), 6.8 \times 10^{3}$ $(0.6 \leq \mathrm{RSD} \leq 5.2)$, and $6.8 \times 10^{1} \mathrm{CFU} \mathrm{mL} \mathrm{L}^{-1}(0.3 \leq \mathrm{RSD} \leq 4.7)$, respectively $(n=3)$. 


\section{Additional file}

Additional file 1: Table S1. Effect of amount of IMMPS on recovery. Table S2 Effect of incubation time on recovery. Table S3 Effect of separation on recovery. Figure S1 Transmission electron micrograph of IMMPs. The electron dense core was about $5 \mathrm{~nm}$.

\section{Competing interests}

The authors declare that they have no competing interests.

\section{Authors' contribution}

DZ and $J$ conceived and designed the experiments. ZS, NH, MJ, ZQ, JW, $B Z, X W$ and JW performed the experiments. ZS, DZ and JL analyzed the data. ZS, DZ and $J \mathrm{~L}$ drafted the manuscript. All authors read and approved the final manuscript.

\section{Acknowledgments}

This study was supported by National Natural Science Foundation of China (81270041 and 21377061) and Natural Science and Technology Supporting Program of Tianjin (11ZCKFSF01100). The English writing was polished by EnPapers.

Received: 26 March 2014 Accepted: 14 May 2014

Published: 20 May 2014

\section{References}

1. Velusamy V, Arshak K, Korostynska O, Oliwa K, Adley C: An overview of foodborne pathogen detection: in the perspective of biosensors. Biotechnol Adv 2010, 28:232-254.

2. Abadias M, Usall J, Anguera M, Solsona C, Vinas I: Microbiological quality of fresh, minimally-processed fruit and vegetables, and sprouts from retail establishments. Int J Food Microbiol 2008, 123:121-129.

3. Wu CJ, Hsueh PR, Ko WC: A new health threat in Europe: Shiga toxin-producing Escherichia coli 0104:H4 infections.J Microbiol Immunol Infect 2011, 44:390-393.

4. Riley LW, Remis RS, Helgerson SD, McGee HB, Wells JG, Davis BR, Hebert RJ, Olcott ES, Johnson LM, Hargrett NT, Blake PA, Cohen ML: Hemorrhagic colitis associated with a rare Escherichia coli serotype. N Engl J Med 1983, 308:681-685.

5. Park S, Kim H, Paek SH, Hong JW, Kim YK: Enzyme-linked immuno-strip biosensor to detect Escherichia coli 0157:H7. Ultramicroscopy 2008, 108:1348-1351.

6. Dweik M, Stringer RC, Dastider SG, Wu Y, Almasri M, Barizuddin S: Specific and targeted detection of viable Escherichia coli 0157:H7 using a sensitive and reusable impedance biosensor with dose and time response studies. Talanta 2012, 94:84-89.

7. Fedio WM, Jinneman KC, Yoshitomi KJ, Zapata R, Wendakoon CN, Browning P, Weagant SD: Detection of E. coli 0157:H7 in raw ground beef by Pathatrix immunomagnetic-separation, real-time PCR and cultural methods. Int J Food Microbiol 2011, 148:87-92.

8. Johnston LM, Elhanafi D, Drake M, Jaykus LA: A simple method for the direct detection of Salmonella and Escherichia coli O157:H7 from raw alfalfa sprouts and spent irrigation water using PCR. J Food Prot 2005, 68:2256-2263.

9. Paton AW, Paton JC: Direct detection and characterization of Shiga toxigenic Escherichia coli by multiplex PCR for stx1, stx2, eae, ehxA, and saa. J Clin Microbiol 2002, 40:271-274.

10. Kumar A, Grover S, Kumar Batish V: Application of multiplex PCR assay based on uidR and fliCH7 genes for detection of Escherichia coli 0157:H7 in milk. J Gen Appl Microbiol 2013, 59:11-19.

11. Wong LY, Cao Y, Balachandran P, Zoder P, Furtado MR, Petrauskene OV, Tebbs RS: Validation of the Applied Biosystems MicroSEQ real-time PCR system for detection of E. coli O157:H7 in food. J AOAC Int 2012, 95:1495-1504

12. Wasilenko JL, Fratamico PM, Narang N, Tillman GE, Ladely S, Simmons M, Cray WC Jr: Influence of primer sequences and DNA extraction method on detection of non-O157 Shiga toxin-producing Escherichia coli in ground beef by real-time PCR targeting the eae, stx, and serogroup-specific genes. J Food Prot 2012, 75:1939-1950.
13. Wang L, Li Y, Mustaphai A: Rapid and simultaneous quantitation of Escherichia coli 0157:H7, Salmonella, and Shigella in ground beef by multiplex real-time PCR and immunomagnetic separation. J Food Prot 2007, 70:1366-1372.

14. Wilkes JG, Tucker RK, Montgomery JA, Cooper WM, Sutherland JB, Buzatu DA: Reduction of food matrix interference by a combination of sample preparation and multi-dimensional gating techniques to facilitate rapid, high sensitivity analysis for Escherichia coli serotype 0157 by flow cytometry. Food Microbiol 2012, 30:281-288.

15. Garcia-Armisen T, Servais P: Enumeration of viable E. coli in rivers and wastewaters by fluorescent in situ hybridization. J Microbiol Methods 2004, 58:269-279.

16. Donhauser SC, Niessner R, Seidel M: Sensitive quantification of Escherichia coli 0157:H7, Salmonella enterica, and Campylobacter jejuni by combining stopped polymerase chain reaction with chemiluminescence flow-through DNA microarray analysis. Anal Chem 2011, 83:3153-3160.

17. Wang Y, Ye Z, Si C, Ying Y: Monitoring of Escherichia coli O157:H7 in food samples using lectin based surface plasmon resonance biosensor. Food Chem 2013, 136:1303-1308.

18. Wang L, Liu Q, Hu Z, Zhang Y, Wu C, Yang M, Wang P: A novel electrochemical biosensor based on dynamic polymerase-extending hybridization for E. coli 0157:H7 DNA detection. Talanta 2009, 78:647-652.

19. Viswanathan S, Rani C, Ho JA: Electrochemical immunosensor for multiplexed detection of food-borne pathogens using nanocrystal bioconjugates and MWCNT screen-printed electrode. Talanta 2012, 94:315-319.

20. Engvall E, Perlmann P: Enzyme-linked immunosorbent assay (ELISA). Quantitative assay of immunoglobulin G. Immunochemistry 1971, 8:871-874.

21. Chunglok W, Wuragil DK, Oaew S, Somasundrum M, Surareungchai W: Immunoassay based on carbon nanotubes-enhanced ELISA for Salmonella enterica serovar Typhimurium. Biosens Bioelectron 2011, 26:3584-3589.

22. Zhu J, Yang Q, Cao L, Dou X, Zhao J, Zhu W, Ding F, Bu RE, Suo S, Ren Y, Li $G$, Ren X: Development of porcine rotavirus vp6 protein based ELISA for differentiation of this virus and other viruses. Virol J 2013, 10:91.

23. Jalallou N, Bandehpour M, Khazan H, Haghighi A, Kazemi B: Evaluation of recombinant sag1 protein for detection of toxoplasma gondii specific immunoglobulin M by ELISA test. Iran J Parasitol 2012, 7:17-21.

24. Byer JD, Struger J, Sverko E, Klawunn P, Todd A: Spatial and seasonal variations in atrazine and metolachlor surface water concentrations in Ontario (Canada) using ELISA. Chemosphere 2011, 82:1155-1160.

25. Strachan NJ, Ogden ID: A sensitive microsphere coagulation ELISA for Escherichia coli 0157:H7 using Russell's viper venom. FEMS Microbiol Lett 2000, 186:79-84.

26. Tuttle J, Gomez T, Doyle MP, Wells JG, Zhao T, Tauxe RV, Griffin PM: Lessons from a large outbreak of Escherichia coli 0157:H7 infections: insights into the infectious dose and method of widespread contamination of hamburger patties. Epidemiol Infect 1999, 122:185-192.

27. Shen ZQ, Wang JF, Qiu ZG, Jin M, Wang XW, Chen ZL, Li JW, Cao FH: QCM immunosensor detection of Escherichia coli O157:H7 based on beacon immunomagnetic nanoparticles and catalytic growth of colloidal gold. Biosens Bioelectron 2011, 26:3376-3381.

28. Su XL, Li Y: A QCM immunosensor for Salmonella detection with simultaneous measurements of resonant frequency and motional resistance. Biosens Bioelectron 2005, 21:840-848.

29. Cheng HY, Lai $\sqcup$, Ko FH: Rapid and sensitive detection of rare cancer cells by the coupling of immunomagnetic nanoparticle separation with ELISA analysis. Int J Nanomedicine 2012, 7:2967-2973.

30. Zhou F, Wang M, Yuan L, Cheng Z, Wu Z, Chen H: Sensitive sandwich ELISA based on a gold nanoparticle layer for cancer detection. Analyst 2012, 137:1779-1784.

31. Tamer U, Cetin D, Suludere Z, Boyaci IH, Temiz HT, Yegenoglu H, Daniel $P$, Dincer I, Elerman Y: Gold-coated iron composite nanospheres targeted the detection of Escherichia coli. Int J Mol Sci 2013, 14:6223-6240.

32. Li F, Zhou R, Zhao K, Chen H, Hu Y: Magnetic beads-based electrochemical immunosensor for detection of pseudorabies virus antibody in swine serum. Talanta 2011, 87:302-306.

33. Wang J, Moore J, Laulhe S, Nantz M, Achilefu S, Kang KA: Fluorophore-gold nanoparticle complex for sensitive optical biosensing and imaging. Nanotechnology 2012, 23:095501.

34. Gan N, Jin H, Li T, Zheng L: Fe(3)O(4)/Au magnetic nanoparticle amplification strategies for ultrasensitive electrochemical immunoassay of alfa-fetoprotein. Int J Nanomedicine 2011, 6:3259-3269. 
35. Huang $\mathrm{SH}$, Liao $\mathrm{MH}$, Chen DH: Direct binding and characterization of lipase onto magnetic nanoparticles. Biotechnol Prog 2003, 19:1095-1100.

36. Pandey P, Singh SP, Arya SK, Gupta V, Datta M, Singh S, Malhotra BD: Application of thiolated gold nanoparticles for the enhancement of glucose oxidase activity. Langmuir 2007, 23:3333-3337.

37. Cudjoe KS, Thorsen LI, Sorensen T, Reseland J, Olsvik O, Granum PE: Detection of Clostridium perfringens type $A$ enterotoxin in faecal and food samples using immunomagnetic separation (IMS)-ELISA. Int J Food Microbiol 1991, 12:313-321.

38. Bai L, Liu X, Fu P, Guo Y: Serotyping and virulence genes of suspected Escherichia coli 0157 strains in food from 2005 to 2007. Wei Sheng Yan Jiu 2010, 39:335-338.

39. Ministry of Health P.R. China: Microbiological examination of food hygiene-examination of Escherichia coli 0157:H7/NM. Standardization Administration PR China 2008. GB/T 4789.36-2008.

40. Duan HL, Shen ZQ, Wang XW, Chao FH, Li JW: Preparation of immunomagnetic iron-dextran nanoparticles and application in rapid isolation of E. coli 0157:H7 from foods. World J Gastroenterol 2005, 11:3660-3664.

41. Ambrosi A, Castaneda MT, Killard AJ, Smyth MR, Alegret S, Merkoci A: Double-codified gold nanolabels for enhanced immunoanalysis. Anal Chem 2007, 79:5232-5240.

42. Kong XL, Qiao FY, Qi H, Li FR: One-step preparation of antibody and oligonucleotide dual-labeled gold nanoparticle bio-probes and their properties. Biotechnol Lett 2008, 30:2071-2077.

43. Nam JM, Thaxton CS, Mirkin CA: Nanoparticle-based bio-bar codes for the ultrasensitive detection of proteins. Science 2003, 301:1884-1886.

44. Sherwani S, Farleigh L, Agarwal N, Loveless S, Robertson N, Hadaschik E, Schnitzler P, Bugert JJ: Seroprevalence of Molluscum contagiosum virus in German and UK populations. PLoS One 2014, 9:e88734.

45. Cutler Jl, Zheng D, Xu X, Giljohann DA, Mirkin CA: Polyvalent oligonucleotide iron oxide nanoparticle "click" conjugates. Nano Lett 2010, 10:1477-1480.

46. Kumar A, Jena PK, Behera S, Lockey RF, Mohapatra S: Multifunctional magnetic nanoparticles for targeted delivery. Nanomedicine 2010, 6:64-69.

47. Liu M, Jia C, Huang Y, Lou X, Yao S, Jin Q, Zhao J, Xiang J: Highly sensitive protein detection using enzyme-labeled gold nanoparticle probes. Analyst 2010, 135:327-331.

48. Almeida C, Sousa JM, Rocha R, Cerqueira L, Fanning S, Azevedo NF, Vieira MJ: Detection of Escherichia coli $\mathrm{O} 157$ by peptide nucleic acid fluorescence in situ hybridization (PNA-FISH) and comparison to a standard culture method. Appl Environ Microbiol 2013, 79:6293-6300.

49. Chan KY, Ye WW, Zhang Y, Xiao LD, Leung PH, Li Y, Yang M: Ultrasensitive detection of E. coli 0157:H7 with biofunctional magnetic bead concentration via nanoporous membrane based electrochemical immunosensor. Biosens Bioelectron 2013, 41:532-537.

doi:10.1186/1757-4749-6-14

Cite this article as: Shen et al: A novel enzyme-linked immunosorbent assay for detection of Escherichia coli 0157:H7 using immunomagnetic and beacon gold nanoparticles. Gut Pathogens 2014 6:14.

\section{Submit your next manuscript to BioMed Central and take full advantage of:}

- Convenient online submission

- Thorough peer review

- No space constraints or color figure charges

- Immediate publication on acceptance

- Inclusion in PubMed, CAS, Scopus and Google Scholar

- Research which is freely available for redistribution

Submit your manuscript at www.biomedcentral.com/submit
C Biomed Central 